\title{
INFLUENCE OF PRODUCT QUALITY ON CONSUMER PURCHASE INTEREST WITH CUSTOMER SATISFACTION AS A VARIABLE INTERVENING IN BLACK ONLINE STORE MARKET LHOKSUMAWE CITY
}

(Case Study on Black Market Online Store Customers in Lhoksumawe City)

\author{
Ari Lasta Irawan ${ }^{1}$, Muhammad Multazam², Rico Nur Ilham ${ }^{3}$, Cengiz Kayacilar ${ }^{4}$ \\ ${ }^{1,2,3}$ Faculty of Economics and Business, Universitas Malikussaleh \\ ${ }^{4}$ Niğde Ömer Halisdemir University, Turkey \\ E-mail: riconurilham@unimal.ac.id
}

\begin{abstract}
This study aims to determine how the influence of product quality on consumer buying interest with customer satisfaction as an intervening variable in the Lhoksumawe City Black Market Online Store. The research method used is the method of qualitative data and quantitative data. While the data used is primary data. The data analysis method in this study uses simple linear regression analysis to obtain a comprehensive picture of the effect of product quality variables on consumer buying interest using the SPSS 25 for Windows program. To find out whether there is a significant effect of the independent variable on the dependent variable, a simple linear regression model is used. The results of hypothesis testing using simple regression analysis and t-test indicate that: the t-table value of the Product Quality variable is $7.644>$ the $t$-table value (df: : 68\%) is 1.995 so it can be concluded that product quality has a positive and significant effect on Consumer Buying Interest. Path analysis shows the direct effect of Product Quality X on Consumer Buying Interest $Y$ of 0.670. Meanwhile, the indirect effect through Customer Satisfaction Z is $0.803 \times 0.273=0.2192$. From the calculation results obtained, it shows that the direct effect through Product Quality $X$ is greater than the indirect effect on Consumer Buying Interest $Y .995$ so that it can be concluded that product quality has a positive and significant effect on consumer buying interest. Path analysis shows the direct effect of Product Quality X on Consumer Buying Interest Y of 0.670. Meanwhile, the indirect effect through Customer Satisfaction $Z$ is $0.803 \times 0.273=0.2192$. From the calculation results obtained, it shows that the direct effect through Product Quality $X$ is greater than the indirect effect on Consumer Buying Interest Y. 995 so that it can be concluded that product quality has a positive and significant effect on consumer buying interest. Path analysis shows the direct effect of Product Quality X on Consumer Buying Interest $Y$ of 0.670. Meanwhile, the indirect effect through Customer Satisfaction $Z$ is $0.803 \times 0.273=0.2192$. From the calculation results obtained, it shows that the direct effect through Product Quality $X$ is greater than the indirect effect on Consumer Buying Interest $Y$.
\end{abstract}

\section{Keywords: Product Quality, Customer Satisfaction, Purchase Interest}

\section{BACKGROUND}

Competition in the increasingly open business world makes entrepreneurs look for the right strategy to market their products. Buying interest is obtained from a learning process and a thought process that forms a perception. According to Sukmawati and Suyono in Pramono quoted from Annafik and Rahardjo (2012), buying interest is part of the behavioral component in consuming attitudes. Consumer buying interest is the stage where consumers form their choices among several brands that are incorporated in the choice set. Then in the end make a purchase on an alternative that he likes the most or the process that consumers go through to buy an item or service based on various considerations. 
The company diversifies its products with consideration to take advantage of existing strengths in its current business in the fields of marketing, production, technology or finance. While Kotler \& Keller translation Bob Sabran (2012:145) defines product quality as follows: "Product quality is the ability of a product to perform its functions, this includes overall durability, reliability, accuracy, ease of operation, and product repair as well as other product attributes" . The quality of a product described in this study is the fact that the quality of the product at the Black Market in Lhoksumawe City is estimated to be of medium quality because the products or goods sold are mostly used or used products,

Richard L. Oliver (in Fandy Tjiptono, 2015: 23) defines customer satisfaction as a feeling of pleasure or disappointment that a person gets from comparing the perceived performance (or outcome) of a product and its expectations. A consumer is satisfied or not, it really depends on the product's performance (Perceived Performance) compared to customer expectations, and whether the consumer interprets the deviation or gap between the performance and the expectation.Consumer satisfaction is defined as a condition where consumer expectations of a product are in accordance with the reality accepted by consumers. If the product is far below expectations, consumers will be disappointed. Conversely, if the product meets expectations, consumers will be satisfied.In this study, the phenomena and facts that are currently happening in this study are that many have used this online buying and selling facility used by all groups.

\section{PREVIOUS RESEARCH}

Previous research is an attempt by researchers to find comparisons and then to find new inspiration for further research. In addition, previous studies help researchers to position research and show the originality of the research. In this section, the researcher includes various previous research results related to the research to be carried out, then makes a summary, both published and unpublished research. The following is a previous study that is still related to the theme that the author is studying.

1. Cintya Damayanti 2015 Effect of Product Quality and Brand Image on Customer Loyalty with Consumer Satisfaction as an Intervening Variable. Semarang State University. The analytical method used in this research is instrument test (validity test and reliability test), classical assumption test, path analysis, and hypothesis testing. The results of this study obtained two path analysis equations, namely $\mathrm{Z}=0.297 \mathrm{X} 1+0.540 \mathrm{X} 2+0.223$ e1 and $\mathrm{Y}=$ $0.156 \mathrm{X} 1+0.172 \mathrm{X} 2+0.644 \mathrm{Z}+0.105 \mathrm{e} 2$. This shows that Product Quality and Brand Image have a direct effect on Customer Loyalty or indirectly through Customer Satisfaction. The conclusion of this research is that product quality and brand image have a direct and indirect effect on building customer loyalty through consumer satisfaction.

2. Mersha Anjani Putri 2015 The Effect of Product Quality and Brand Image on Repurchase With Customer Satisfaction as an Intervening Variable on Sari Ayu lipstick consumers in the city of Semarang, Faculty of Social and Political Sciences, Diponegoro University. Product Quality on Customer Satisfaction on Sari Ayu products in the city of Semarang has been proven. This is evidenced by the results of the calculation of the t-count value of 8.581 which is greater than the t-table $(1.984)$ with a significant $(0.000)<(0.05)$ and the regression coefficient value of Product Quality of 0.407 . This positive product quality coefficient indicates that the better the assessment of product quality, the better the customer satisfaction for Sari Ayu products in the eyes of consumers in the city of Semarang. The test results are reinforced by the results of the calculation of the coefficient of determination, which is $42.9 \%$, meaning that the Customer Satisfaction variable can be explained by the Product Quality variable of $42.9 \%$. So that the first hypothesis which 
reads "It is suspected that product quality variables have an influence on customer satisfaction that occurs in users of Sari Ayu products in the city of Semarang" is accepted. The second hypothesis states that there is an influence between Brand Image on Customer Satisfaction on Sari Ayu products in the city of Semarang has been proven. This is evidenced by research on the results of the calculation of the t-count value of 6.234 which is greater than the t-table $(1.984)$ with a significant $(0.000)<(0.05)$ and the value of the Brand Image regression coefficient of 0.381 . This positive brand image coefficient indicates that the better the assessment of the brand image, the better the customer satisfaction for Sari Ayu products in the eyes of consumers in the city of Semarang. The test results are reinforced by the results of the calculation of the coefficient of determination that is equal to $28.4 \%$, which means that the Customer Satisfaction variable can be explained by the Brand Image variable of $28.4 \%$. So that the second hypothesis which reads "It is suspected that the Brand Image variable has an influence on customer satisfaction that occurs in users of Sari Ayu products in the city of Semarang" is accepted. it means that the variable Customer Satisfaction can be explained by the variable Brand Image of $28.4 \%$. So that the second hypothesis which reads "It is suspected that the Brand Image variable has an influence on customer satisfaction that occurs in users of Sari Ayu products in the city of Semarang" is accepted. it means that the variable Customer Satisfaction can be explained by the variable Brand Image of $28.4 \%$. So that the second hypothesis which reads "It is suspected that the Brand Image variable has an influence on customer satisfaction that occurs in users of Sari Ayu products in the city of Semarang" is accepted.

3. Nurhasanah 2018 Department of Social Science Education Economic Education Study Program, University of Lampung. Effect of Product Quality, Brand Image, Service Quality on Consumer Loyalty through Customer Satisfaction of Master Fried Chicken and Burger Bandar Lampung. This research is motivated by the level of fluctuating sales. The purpose of this study was to determine how much influence product quality, brand image, service quality had on consumer loyalty through customer satisfaction of Master Fried Chicken and Burger Bandar Lampung partially or simultaneously. The method used in this research is descriptive verification with ex post facto and survey approaches. The population in this study were 135 consumers with a sample of 100 consumers. Determination of the sample is done using the Non-Probability Sampling Method using the Accidental Sampling Technique. Each question posed to the respondent is measured based on the Differential Semantic scale.

4. Wawan Setiawan 2019 The Influence of Product Quality and Price on Interest in Buying Back Rice Batang Gadis at Agen s. Riyadi Through Consumer Satisfaction as an Intervening Variable.The purpose of this study was to determine the effect of product quality and price on the interest in buying back rice stems of girls at Agen S. Riyadi through consumer satisfaction as an intervening variable. With the sampling technique using non-probability sampling technique where sampling that does not provide equal opportunities or opportunities for each element or member of the population to be selected as a sample. The population in this study, namely consumers of Agent S. Riyadi and 53 people were taken as samples and tested with validity test equipment, reliability tests, mediation tests and hypothesis testing with the help of the WarpPLS version 3.0 program. $\mathrm{X} 1)$ on the Consumer Satisfaction variable (Z) with a positive path coefficient of 0.93 with a $\mathrm{P}$ value $<0,001$ is smaller than 0.05 and $\mathrm{R}$-Square is 0.87 , it means that product quality has a positive effect on consumer satisfaction with a large effect of $87 \%$. The results of the hypothesis test for the Price variable (X2) on Consumer Satisfaction (Z) with a positive Path Coefficients value of 0.83 with a $\mathrm{p}$ value $<0.001$ smaller than 0.05 and an R-Square value of 0.78 which means that the price has a positive effect on consumer satisfaction with a large influence of $78 \%$. Hypothesis test results Consumer satisfaction variable $(\mathrm{Z})$ on repurchase interest with path coefficients value positive 0.98 with $\mathrm{P}$-values $<0.001$ smaller 
than 0.05 and R-Square worth 0.97 this means that consumer satisfaction has a positive effect to repurchase interest, with a large effect of $97 \% .87$ it means that product quality has a positive effect on consumer satisfaction with a large influence of $87 \%$. The results of the hypothesis test for the Price variable (X2) on Consumer Satisfaction (Z) with a positive Path Coefficients value of 0.83 with a $\mathrm{p}$ value $<0.001$ smaller than 0.05 and an R-Square value of 0.78 which means that the price has a positive effect on consumer satisfaction with a large influence of $78 \%$. Hypothesis test results Consumer satisfaction variable $(\mathrm{Z})$ on repurchase interest with path coefficients value positive 0.98 with $\mathrm{P}$-values $<0.001$ smaller than 0.05 and R-Square worth 0.97 this means that consumer satisfaction has a positive effect to repurchase interest, with a large effect of $97 \% .87$ it means that product quality has a positive effect on consumer satisfaction with a large influence of $87 \%$. The results of the hypothesis test for the Price variable (X2) on Consumer Satisfaction (Z) with a positive Path Coefficients value of 0.83 with a $\mathrm{p}$ value $<0.001$ smaller than 0.05 and an $\mathrm{R}$-Square value of 0.78 which means that the price has a positive effect on consumer satisfaction with a large influence of $78 \%$. Hypothesis test results Consumer satisfaction variable $(\mathrm{Z})$ on repurchase interest with path coefficients value positive 0.98 with $\mathrm{P}$-values $<0.001$ smaller than 0.05 and R-Square worth 0.97 this means that consumer satisfaction has a positive effect to repurchase interest, with a large effect of $97 \%$. The results of the hypothesis test for the Price variable (X2) on Consumer Satisfaction (Z) with a positive Path Coefficients value of 0.83 with a $p$ value $<0.001$ smaller than 0.05 and an $R$-Square value of 0.78 which means that the price has a positive effect on consumer satisfaction with a large influence of $78 \%$. Hypothesis test results Consumer satisfaction variable $(\mathrm{Z})$ on repurchase interest with path coefficients value positive 0.98 with $\mathrm{P}$-values $<0.001$ smaller than 0.05 and R-Square worth 0.97 this means that consumer satisfaction has a positive effect to repurchase interest, with a large effect of $97 \%$. The results of the hypothesis test for the Price variable (X2) on Consumer Satisfaction (Z) with a positive Path Coefficients value of 0.83 with a $p$ value $<0.001$ smaller than 0.05 and an $\mathrm{R}$-Square value of 0.78 which means that the price has a positive effect on consumer satisfaction with a large influence of $78 \%$. Hypothesis test results Consumer satisfaction variable $(\mathrm{Z})$ on repurchase interest with path coefficients value positive 0.98 with $\mathrm{P}$-values $<0.001$ smaller than 0.05 and $\mathrm{R}$-Square worth 0.97 this means that consumer satisfaction has a positive effect to repurchase interest, with a large effect of $97 \% .78$ it means that the price has a positive effect on consumer satisfaction with a large influence of $78 \%$. Hypothesis test results Consumer satisfaction variable $(Z)$ on repurchase interest with path coefficients value positive 0.98 with $\mathrm{P}$-values $<0.001$ smaller than 0.05 and R-Square worth 0.97 this means that consumer satisfaction has a positive effect to repurchase interest, with a large effect of $97 \% .78$ it means that the price has a positive effect on consumer satisfaction with a large influence of $78 \%$. Hypothesis test results Consumer satisfaction variable $(\mathrm{Z})$ on repurchase interest with path coefficients value positive 0.98 with P-values $<0.001$ smaller than 0.05 and R-Square worth 0.97 this means that consumer satisfaction has a positive effect to repurchase interest, with a large effect of $97 \%$.

\section{IMPLEMENTATION METHOD}

3.1 Types and Sources of Data

\subsubsection{Data Type}

This research is a quantitative research, Quantitative data according to Sugiyono (2015) is data in the form of numbers or qualitative data that is numbered. 


\subsubsection{Data Source}

Primary Data is a data source that directly provides data to data collectors. In this study, primary data in the form of data from questionnaires and interviews conducted by researchers.

Secondary data is a source that does not directly provide data to data collectors, for example through other people or through documents.

\subsection{Data Collection Techniques}

\subsubsection{Questionnaire}

Questionnaires or questionnaires are a number of questions or written statements about factual data or opinions relating to the respondent, which are considered facts or truths that are known and need to be answered by the respondent (Suroyo anwar 2009:168.). In this questionnaire, a closed question model will be used, namely questions that have been accompanied by previous alternative answers so that respondents can choose one of these alternative answers.

The data processing in this study used a Likert Scale.According to Sugiyono (2013:132), "Likert scale is used to measure attitudes, opinions and perceptions of a person or group of people about social phenomena".

In answering this Likert scale, the respondent only gives a mark, for example a checklist or a cross on the answer chosen according to the statement. The questionnaire that has been filled out by the respondent needs to be scored. The following is the weight of the assessment on the Likert scale.

\subsubsection{Interview}

According to Sugiyono (2015:231) interviews are data collection techniques if researchers want to conduct a preliminary study to find problems that must be investigated, but also if researchers want to know things from respondents more deeply.

\subsubsection{Literature Study}

Literature study, according to Nazir (2013), is a data collection technique by conducting a review study of books, literatures, notes, and reports that have to do with the problem being solved.

3.3 Population and Sample

3.3.1 Population

The population is a generalization area consisting of objects or subjects that have certain qualities and characteristics determined by researchers to be studied and drawn conclusions (Sugiyono, 2017). In this study, the population is the Consumers of the Black Market Online Store in Lhoksumawe City, as many as 30 people.

\subsubsection{Sample}

Sample According to (Sugiyono, 2016:81) that: "The sample is part of the number and characteristics possessed by the population. Measurement of the sample is a step to determine the size of the sample taken in carrying out research on an object. To determine the size of the sample can be done with statistics or based on research estimates. This sampling must be carried out in such a way that a sample is obtained that can truly function or can describe the actual state of the population, in other terms it must be representative. Because the target population is less than 100, the sampling technique used is the census method, where the entire population of the Lhoksumawe City Black Market Online Store Consumers is 30 people.

\subsection{Definition of Variable Operations}

Definition of Variables According to Sugiyono (2013:58) the definition of a variable is: "An attribute or nature or value of a person, object or activity that has a certain variation set by researchers to study and draw conclusions". 
The definition of independent variables according to Sugiyono (2013:39) is a variable that affects or is the cause of the change or the emergence of the dependent variable (dependent).

3.4.2 Bound Variable (Developed Variable)

The definition of the dependent variable according to Sugiyono (2013:39) is a variable that is influenced or becomes a result because of the independent variable.

\subsubsection{Intervening Variable $(\mathrm{Z})$}

Sugiyono (2013:61) states that: Intervening variables are variables that theoretically affect the relationship between the independent variable and the dependent variable, but cannot be observed and measured. This variable is an intervening variable or between which lies between the independent and dependent variables, so that the independent variable does not directly affect the change or emergence of the dependent variable ".

3.5 Data Analysis Techniques

Data analysis is a desire to group, make a sequence, manipulate and abbreviate data so that it is easy to read and understand. In other words, data analysis activities are raw data that has been collected and needs to be categorized or divided into several categories or groups, abbreviated in such a way that the data can answer the problem according to the research objectives and can test hypotheses (Silaen and Widiyono, 2013).

\section{RESEARCH RESULTS}

\subsection{Partial t-test}

\begin{tabular}{|c|c|c|c|c|c|c|c|}
\hline \multirow[b]{3}{*}{ Model } & \multicolumn{4}{|c|}{ Coefficientsa } & \multirow[b]{3}{*}{ Sig. } & & \\
\hline & \multicolumn{2}{|c|}{$\begin{array}{c}\text { Unstandardized } \\
\text { Coefficients }\end{array}$} & \multirow{2}{*}{$\begin{array}{c}\text { Standardized } \\
\text { Coefficients } \\
\text { Beta }\end{array}$} & \multirow[b]{2}{*}{ t } & & \multicolumn{2}{|c|}{$\begin{array}{l}\text { Collinearity } \\
\text { Statistics }\end{array}$} \\
\hline & $\mathrm{B}$ & $\begin{array}{l}\text { Std. } \\
\text { Error }\end{array}$ & & & & Tolerance & VIF \\
\hline 1 (Constant) & 5.104 & 1.026 & & 4.974 & .000 & & \\
\hline Quality_Product_X & .681 & .061 & .803 & 11.107 & .000 & 1,000 & 1,000 \\
\hline
\end{tabular}

a. Dependent Variable: Customer_Satisfaction_Z

Hypothesis Testing the effect of Product Quality variable (X) on the Satisfaction variable Customer (Z).

The form of hypothesis testing based on statistics can be described as following :

Decision Making Criteria:

1) Accept HO If tcount $<$ ttable or -tcount $>$ - ttable orvalue Sig. $>0.05$.

2) Reject $\mathrm{HO}$ If tcount ttable or -tcount - ttable orSig. $<0.05$.

From the table above, the tcount value is 11.107 With $=5 \%$, ttable $(5 \%$; $\mathrm{nk}=68)$ the ttable value is 1.995 . From the description it can be seen that tcount (11.107) > ttable (1.995), as well as the significance value of $0.000<0.05$, it can be concluded that the first hypothesis is accepted, meaning that the Product Quality variable (X) has a positive and significant effect on Customer Satisfaction (Z). In line with research conducted by Mersha Anjani 
Putri 2015 with the title The Effect of Product Quality and Brand Image on Repurchase with Customer Satisfaction as an Intervening Variable on Sari Ayu lipstick consumers in the city of Semarang, Faculty of Social and Political Sciences, Diponegoro University.

\begin{tabular}{|c|c|c|c|c|c|c|c|}
\hline \multirow[b]{3}{*}{ Model } & \multicolumn{4}{|c|}{ Coefficientsa } & \multirow[b]{3}{*}{ Sig. } & \multirow{2}{*}{\multicolumn{2}{|c|}{$\begin{array}{c}\text { Collinearity } \\
\text { Statistics }\end{array}$}} \\
\hline & \multicolumn{2}{|c|}{$\begin{array}{c}\text { Unstandardized } \\
\text { Coefficients }\end{array}$} & \multirow{2}{*}{$\begin{array}{c}\text { Standardized } \\
\text { Coefficients } \\
\text { Beta } \\
\end{array}$} & \multirow[b]{2}{*}{$t$} & & & \\
\hline & $\mathrm{B}$ & $\begin{array}{l}\text { Std. } \\
\text { Error }\end{array}$ & & & & Tolerance & VIF \\
\hline 1 (Constant) & 1.156 & .973 & & 1.188 & .239 & & \\
\hline Quality_Product_X & .638 & .084 & .670 & 7,644 & .000 & .355 & 2.814 \\
\hline Customer_Satisfaction_Z & .307 & .098 & .273 & 3.121 & .003 & .355 & 2.814 \\
\hline
\end{tabular}

a. Dependent Variable: Interest_Beli_Y

Hypothesis Testing the Effect of Product Quality (X) to Purchase Interest (Y)

The form of hypothesis testing based on statistics can be described as follows:

Decision Making Criteria:

a) Accept HO If tcount $<$ ttable or -tcount $>$ - ttable orvalue Sig. $>0.05$

b) Reject HO If tcount ttable or -tcount - ttable orSig. $<0.05$

From the table above, the tcount value is 7.644 . With $=5 \%$, table $(5 \%$; nk $=68)$ the ttable value is 1.995 . From the description it can be seen that tcount (7.644) > ttable (1.995), and the significance value is $0.000<0.05$, it can be concluded that the second hypothesis is accepted, meaning that Product quality (X) has a positive and significant effect to Purchase Interest (Y). In line with Wawan Setiawan 2019 with the title The Influence of Product Quality and Price on Interest in Buying Back Rice Batang Gadis at Agen s. Riyadi Through Consumer Satisfaction as an Intervening Variable.

Hypothesis Testing the Effect of Customer Satisfaction (Z) on Purchase Interest (Y)

The form of hypothesis testing based on statistics can be described as follows:

Decision Making Criteria:

a) Accept HO If tcount $<$ ttable or -tcount $>$ - ttable orvalue Sig. $>0.05$

b) Reject HO If tcount ttable or -tcount - ttable orSig. $<0.05$

From table 4.17, the tcount value is 3.121 . With $=5 \%$, table $(5 \% ; \mathrm{nk}=68)$ the ttable value is 1.995. From the description it can be seen that tcount (3.121) > ttable (1.995), and the significance value is $0.003<0.05$, it can be concluded that the third hypothesis is accepted, meaning that Customer Satisfaction ( $Z$ ) take effectpositive and significantto Purchase Interest (Y). This research is not in line with Wawan Setiawan's research in 2019 The Effect of Product Quality and Price on Interest in Buying Rice Batang Gadis at Agen s. Riyadi Through Consumer Satisfaction as an Intervening Variable.

\subsection{Path Analysis}




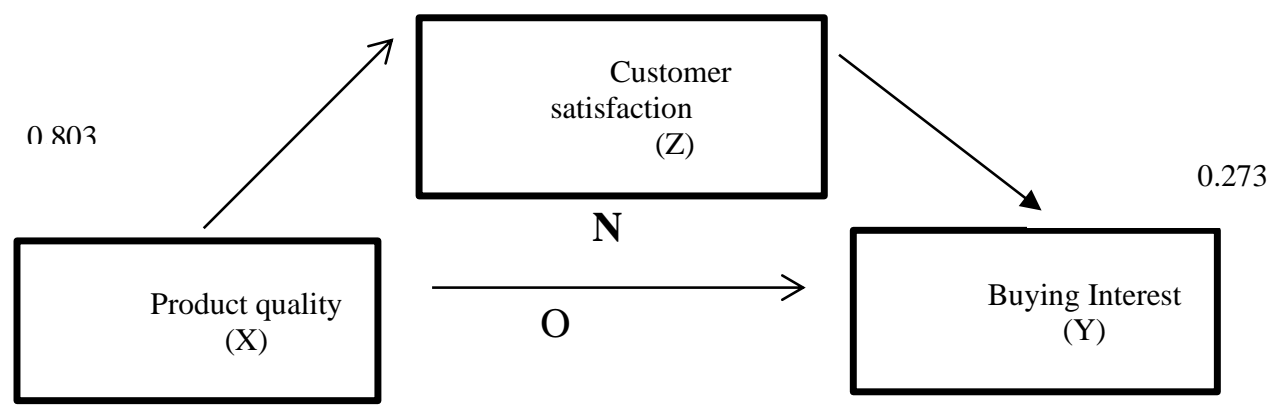

0.670

Figure 4.5 Path Analysis

Path analysis shows that the direct effect of Product Quality X on Consumer Y's Purchase Interest is 0.670. Meanwhile, the indirect effect through Customer Satisfaction $\mathrm{Z}$ is $0.803 \mathrm{x}$ $0.273=0.2192$. From the calculation results obtained, it shows that the direct effect through Product Quality X is greater than the indirect effect on Consumer Buying Interest Y.

\section{CONCLUSION}

1. Based on the results of the study, the researchers concluded that the product quality onThe Lhoksumawe City Black Online Store is descriptively in the high classification or in the good category. This can be seen from the product quality variable (X) significant effect to customer satisfaction (Z). Theoretically, customer satisfaction needs an effort to improve the quality of a good product when customer satisfaction decreases by providing the right product quality that will increase customer satisfaction.

2. Based on the results of the study, the researchers concluded that the product quality onThe Lhoksumawe City Black Market Online Store is descriptively in a high classification or has a lot of influence on buying interest. Where is the product quality (X)significant effect on buying interest $(\mathrm{Y})$.

3. Based on the results of the study, the researchers concluded that the customer satisfaction shown tothere isThe Lhoksumawe City Black Market Online Store is descriptively in the high classification or in customer satisfaction and is well received. It can be seen from customer satisfaction $(\mathrm{Z})$ has a significant effect on buying interest $(\mathrm{Y})$

\section{REFERENCES}

Arikunto, Suharsimi. 2010. Research Procedures, A Practical Approach. Rinneks Cipta.Jakarta

Basu Swastha. 2009. Sales Management. Yogyakarta: BPFE

Basu Swasta and Hani Handoko, 2010, Marketing Management: Analysis and

Consumer behavior. BPFE. Yogyakarta.

Burhan Bungin. 2009. Qualitative Data Research Analysis. Jakarta: King of Grafindo

Cahyono, M. (2008). The effect of service quality on customer satisfaction at brown salon at Tunjungan Plaza Surabaya (Doctoral dissertation, Petra Christian University).

C Mowen, John. Michael Minor. (2010). Consumer behavior. Jakarta. Erlangga

Durianto, Darmadi. 2013. Strategy to Conquer the Market Through Equity Research and Brand Behavior (10th cet.). Jakarta: PT Gramedia Pustaka Utama

Engel et al. (2010). Consumer behavior. Sixth Edition, volume 1.: Binarupa Aksara. Jakarta. 
Ghozali, I. 2011. Application of Multivariate Analysis with SPSS Program. Edition II. Diponegoro University Publishing Agency. Semarang.

Haryanto, RA (2013). Promotion strategy, product quality, service quality on customer satisfaction at McDonald's Manado restaurant. Journal of Research in Economics, Management, Business and Accounting, 1(4).

Kotler, P. 2012. Marketing Management, Volume 1. PT. Gramedia Group Index. Jakarta. 2010. Marketing Management, Volume 2. PT. Gramedia Group Index. Jakarta.

Kotler, P. and G, Armstrong. 2012. Marketing principles 2. Twelfth edition. Jakarta : Erlangga.

Kotler, P. and G, Armstrong. 2009. Principles of marketing 2. Twelfth edition. : Erlangga. Jakarta.

Kotler, P and KL Keller. 2012. Marketing Management. Edition 13. Volume I.: Erlangga.s Jakarta. Kuncoro, M. 2009. Research Methods for Business and Economics. PT. Salemba Four. Jakarta.

Noor. Juliansyah, 2011, Research Methodology, Prenada Media Group, Jakarta

Rizan, M., \& Andika, F. (2011). Effect of Product Quality and Service Quality on Customer Satisfaction (Suzuki Customer Survey, Fatmawati Dealer,). JRMSI-Indonesian Science Management Research Journal, 2(2), 130-150. South Jakarta.

Saidani, B., \& Arifin, S. (2012). The effect of product quality and service quality on consumer satisfaction and buying interest in the ranch market. JRMSI-Indonesian Science Management Research Journal, 3(1), 1-22.

Sugiyono. 2012. Understanding qualitative research. Bandung. Alphabet.

Sumarwan, U. 2011. Consumer Behavior: Theory and Its Application in Marketing. PT. Ghalia Indonesia, Bogor.

Tengku Putri Protect the Moon. 2017. The Effect of Product and Price Diversification on Consumer Satisfaction at the skipper Jasmine Langsa. Faculty of Economics, University.

Tjiptono, F. 2010. Marketing Strategy. First Edition. Andi Offset Publisher. Yogyakarta. 
Volume 1 Issue 1 (2021)

INFLUENCE OF PRODUCT QUALITY ON CONSUMER PURCHASE INTEREST WITH CUSTOMER SATISFACTION AS A VARIABLE INTERVENING IN BLACK ONLINE STORE MARKET LHOKSUMAWE CITY

(Case Study on Black Market Online Store Customers in Lhoksumawe City)

Ari Lasta Irawan, Muhammad Multazam, Rico Nur Ilham 